\title{
Effective Management of Cucumber Powdery Mildew with Essential Oils
}

\author{
Yasser S. Mostafa ${ }^{1}$, Mohamed Hashem ${ }^{1,2, * \mathbb{D}}$, Ali M. Alshehri ${ }^{1}$, Saad Alamri ${ }^{1}$, Ebrahem M. Eid ${ }^{1,3}$ (D), \\ El-Sayed H.E. Ziedan ${ }^{4}$ and Sulaiman A. Alrumman ${ }^{1}$ (D) \\ 1 Biological Science Department, Faculty of Science, King Khalid University, Abha 61321, Saudi Arabia; \\ Ysmosutafa@kku.edu.sa (Y.S.M.); aahshehry@kku.edu.sa (A.M.A.); saralomari@kku.edu.sa (S.A.); \\ ebrahem.eid@sci.kfs.edu.eg (E.M.E.); Salrumman@kku.edu.sa (S.A.A.) \\ 2 Botany and Microbiology Department, Faculty of Science, Assiut University, Assiut 71516, Egypt \\ 3 Botany Department, Faculty of Science, Kafrelsheikh University, Kafr El-Sheikh 33516, Egypt \\ 4 Plant Pathology, National Research, Dokki, Cairo 12622, Egypt; eh.ziedan@nrc.sci.eg \\ * Correspondence: mhashem@kku.edu.sa; Tel.: +966-172-417-625
}

Citation: Mostafa, Y.S.; Hashem, M.; Alshehri, A.M.; Alamri, S.; Eid, E.M.; Ziedan, E.-S.H.; Alrumman, S.A. Effective Management of Cucumber Powdery Mildew with Essential Oils. Agriculture 2021, 11, 1177. https:// doi.org/10.3390/agriculture11111177

Academic Editors: Renata Bažok and Maja Čačija

Received: 5 November 2021

Accepted: 20 November 2021

Published: 22 November 2021

Publisher's Note: MDPI stays neutral with regard to jurisdictional claims in published maps and institutional affiliations.

Copyright: (C) 2021 by the authors. Licensee MDPI, Basel, Switzerland. This article is an open access article distributed under the terms and conditions of the Creative Commons Attribution (CC BY) license (https:/ / creativecommons.org/licenses/by/ $4.0 /)$.

\begin{abstract}
This research evaluated the efficacy of essential oils in the management of cucumber powdery mildew. Essential oils of lemongrass, lemon, thyme, peppermint, abundance blend, purification blend, and thieves blend were tested in vitro and under greenhouse conditions in two separate experiments. The effects of essential oils were tested against powdery mildew disease at concentrations of 1.0-2.5 mL/L, and the consequent impact of the oils on plant growth was evaluated. Powdery mildew fungus, Podosphaera xanthii, was identified using sequencing of the ITS region. The essential oils significantly reduced disease incidence up to $77.3 \%$ compared with the positive control $(p<0.5)$. Moreover, the essential oils increased the plant length (up to $187 \mathrm{~cm}$ ), leaf area (up to $27.5 \mathrm{~cm}^{2}$ ), fresh weight (up to $123 \mathrm{~g}$ ), dry weight (up to $22.5 \mathrm{~g}$ ), number of flowers (16.3), and metabolite content compared with the positive control $(p<0.5)$. Cell membrane injury decreased significantly in the oil-treated pants $(p<0.5)$, indicating the protective effect of essential oils. This study recommends the application of essential oils in an appropriate dose $(2.5 \mathrm{~mL} / \mathrm{L})$ to protect cucumber plants against powdery mildew. Overdose of the oils (more than $2.5 \mathrm{~mL} / \mathrm{L}$ ) should be avoided due to adverse effects.
\end{abstract}

Keywords: cucumber; essential oils; crop management; disease control; Podosphaera xanthii; powdery mildew

\section{Introduction}

Cucumber (Cucumis sativus L.) is one of the most important and widely distributed vegetable crops due to its rapid growth and early maturity. Cucumber is produced either in protected houses or in open fields [1,2]. The global cultivation of this crop covers $2,231,402$ hectares, with production of about 87.805 tons [3]. However, cultivation in the Arab countries is about 67,000 hectares. Among these countries, Saudi Arabia cultivates 11,764 hectares and produces 149,074 tons, with a production rate of 1.27 tones/ha [4]. Cucumber fruit is a good source of minerals and vitamins and delivers $\mathrm{Na}, \mathrm{Mg}, \mathrm{K}, \mathrm{Ca}, \mathrm{S}, \mathrm{Si}$, $\mathrm{F}$, and Fe. Cucumber contains carbohydrates, protein, thiamin, riboflavin, vitamin $\mathrm{C}$, and niacin. Moreover, the presence of minerals is important to maintain human blood alkalinity. In addition, the vitamins in cucumber fruit facilitate strength and the growth of connecting tissue, as well as relieve joint pain. Cucumber also contains secoisolariciresinol, lignans, lariciresinol, and pinoresinol, which help to reduce the risks of different cancers [5].

In many countries of the Middle East, such as Egypt, open fields are the common cultivation areas for cucumbers [6]. However, in other countries suffering from water shortages, such as Gulf countries, greenhouses are the main production sources of cucumber [7]. In Saudi Arabia, the total greenhouse area for cucumber production in 2013 was 2605 hectares, which produced 236,087 tons [8]. 
This crop is affected by several destructive diseases that reduce its productivity and increase production costs. Among these diseases, powdery mildew, caused by the fungus Podosphaera xanthii (Castagne) U. Braun \& Shishkoff (Syn. Sphaerotheca fuliginea), represents a challenge for both growers and researchers $[9,10]$. This pathogen infects the shoot system and causes a severe reduction in crop productivity $[11,12]$. The conidia of $P$. xanthii are typically airborne, take approximately $24 \mathrm{~h}$ to germinate, and invade plant tissue [13]. Disease development usually takes 7 days when relative humidity exceeds $75 \%$ [14].

This disease is controlled by synthetic fungicides, but these compounds can lead to pathogen resistance towards the relevant chemical agents [15]. Moreover, global public awareness has increased regarding the contamination of the environment and food sources with chemicals and pesticides [16], which has motivated researchers and producers to seek a safe alternative to manage this vital crop.

The management of diseases using resistant cultivars has been very successful in many cases; however, due to pathogen adaptation, the degree of protection achieved with resistant cultivars varies and is not always sufficient as a single-management practice. Some reports noted that resistant cultivars can produce less than susceptible cultivars [17]. Thus, the use of resistant cultivars alone may not be a suitable method to manage powdery mildew and achieve good crop yields. The successful control of powdery mildew would require an integrated pest management (IPM) that includes the application of good cultural practices, as well as the selection of appropriate resistant varieties and fungicides. Good cultural practices should focus on shortening the period of leaf wetness through, e.g., early planting, good circulation of air, expanding planting space, and avoiding overhead irrigation $[18,19]$. Currently, there is a global preference for vegetable production using organic farming, which relies on safe biopesticides and biofertilizers. However, the application of natural biopesticides instead of chemicals in the control of diseases still represents a major challenge for researchers [20].

Biopesticides play a significant role as alternatives for chemical pesticides and as a part of the IPM in controlling the powdery mildews of cucurbits [17], but some of these biopesticides may have negative effects on saprophytic microorganisms [21]. Biofungicides are natural products derived from microorganisms, plants, animals, or minerals that can suppress fungal organisms directly or by stimulating the defense responses of plants. Biofungicides generally have a narrow spectrum, with low toxicity to the non-target organisms, quick decomposition, and a low negative impact on the environment. Biofungicides based on bioagents, such Bacillus subtilis, potassium bicarbonate, phosphorous acid, Tricon, and oils, were approved to control powdery mildew in some crops $[17,22]$. Currently, several biofungicides have been registered and approved for controlling the powdery mildew of cucumber in many countries [17,23]. In the Middle East, however, there is a lack of information on the status of biopesticide availability and application. While organic farmers and growers do their best to avoid chemical pesticides through the application of good cultivation practices and organic fertilizers, the normal cultivation of cucumber mainly relies on chemical fungicides to control powdery mildew.

As low-risk substances, natural products of plant origin are an important group of candidates for inclusion in IPM [24]. Despite the publication of reports attesting to the antimicrobial activities of plant extracts and essential oils, relatively few natural products are used in crop protection [25]. Natural compounds have lower perseverance and toxicity than synthetic pesticides, which reduces their potential negative impacts on the environment [18]. Essential oils (EOs) are natural compounds used for many purposes due to their antimicrobial properties [26-28]. Essential oils present a wide spectrum of activities against diverse plant diseases [29] and have been successfully applied in the suppression of many plant pathogens causing foliar diseases, including powdery mildews $[18,29,30]$ and leaf spots [31]. The application of essential oils as an alternative to chemical pesticides in the control of plant diseases is associated with potential advantages because these oils are relatively non-toxic to mammals and fish. Essential oils are usually rich in various compounds, including 20 to 60 active substances [32]. Furthermore, microbial resistance to 
essential oils develops more slowly than resistance to other compounds due to the complex mixtures of constituents that characterize certain oils [33]. Increasingly more EOs have shown interesting activities from an agricultural perspective against a broad spectrum of microorganisms in vitro and in situ [32]. Although many studies have reported the efficacy of EOs at a lab scale, plant-pathogen-EO interactions remain understudied, leading to a lack of field knowledge [32,34]. Based on the scarcity of works from field trials on the use of EOs for controlling plant diseases, the present study offers valuable information about the efficiency of EOs in suppressing powdery mildew on a large scale.

This study aimed to test the efficacy of essential oils, individually or in a mixture, in the management of cucumber powdery mildew via the application of low doses. The fungitoxic effects of the essential oils were evaluated in terms of the development of powdery mildew fungus, P. xanthii. Additionally, the effects of essential oils on the morphological and physiological characteristics of the treated plants were assessed.

\section{Materials and Methods}

\subsection{The Pathogen}

Cucumber powdery mildew fungus (P. xanthii KKUY-6001) was isolated from naturally infected cucumber plants (cv Sovana F1) grown in an open field in the Asir region of Saudi Arabia. The fungal strain was examined for its homogenous conidia and type of conidiophore to confirm its identification as a monoculture strain. Conidia of the fungus were scraped from the diseased leaves and suspended in sterilized tap water to derive a concentration of $10^{5}$ spores $/ \mathrm{mL}$. The suspension was then used as an inoculum for the pathogenicity trials. P. xanthii KKUY-6001 was identified based on the morphology of its mycelia and conidia, consistent with Braun and Takamatsu [35], and its identity was confirmed by sequencing its internal transcribed spacer (ITS) region of DNA. Fungal DNA was extracted from the conidial suspension using a Qiagen DNeasy Plant Mini Kit, following the protocol described in the manufacturer's instructions. Primers ITS1-F (CTTGGT CAT TTA GAG GAA GTA A) and ITS4 R (TCC TCCGCT TATTGA TAT GC) were applied to amplify the ITS region of the fungal DNA, following the protocol of White et al. [36]. Polymerase chain reaction (PCR) was performed in a final volume of $50 \mu \mathrm{L}$ containing GoTaq green master mix (Promega, Madison, WI, USA), $1 \mu \mathrm{L}$ of each primer at a concentration of $0.5 \mathrm{mM}$, and $1 \mu \mathrm{L}$ of template DNA, following Chen et al. [37]. Amplification of the ITS region was undertaken using PCR under the following conditions: initial denaturation at $95^{\circ} \mathrm{C}$ for $5 \mathrm{~min}$, followed by 40 cycles at $94^{\circ} \mathrm{C}$ for $1 \mathrm{~min}, 55^{\circ} \mathrm{C}$ for $1 \mathrm{~min}$, and $72{ }^{\circ} \mathrm{C}$ for $1 \mathrm{~min}$; final extension at $72{ }^{\circ} \mathrm{C}$ for $10 \mathrm{~min}$; and holding at $4{ }^{\circ} \mathrm{C}$. Amplified products were examined using electrophoresis in 1.5\% agarose gels in a trisborate-EDTA (TBE) buffer. Purification and sequencing of the PCR product was carried out by the Macrogen Company, Korea. To determine the closest available sequences, the sequence of the ITS region of the fungal pathogen was compared to similar available sequences in the GenBank database using the BLAST search tool.

\subsection{Essential Oils}

Seven types of essential oils were purchased from The Essential Oil Company (Portland, OR, USA): thyme, lemongrass, lemon, peppermint, abundance blend, purification blend, and thieves blend, in addition to the oil mixture (lemon + lemongrass + thyme + peppermint in equal proportions). The abundance blend contained equal concentrations of lavender, mandarin, lemon, and bios de rose; the purification blend contained equal concentrations of juniper berry, grapefruit, sweet fennel, lemon, cypress, and geranium; and the thieves blend contained equal concentrations of clove bud, lemon, cinnamon, rosemary, lavender, and cedarwood. These essential oils were assessed for their efficacy in controlling cucumber powdery mildew. 


\subsection{In Vitro Leaf Discs Bioassay}

The in vitro leaflet bioassay was performed by adapting the method of Nelson [38]. Briefly, cucumber leaves (cv Sovana F1) naturally infected with powdery mildew were cut into discs $(0.5 \mathrm{~cm}$ in diameter) using a cork borer. Five discs were immersed in serial concentrations of essential oils $(1.0,1.5,2.0$, and $2.5 \mathrm{~mL} / \mathrm{L})$ in a petri dish for $2 \mathrm{~h}$. The essential oils were then emulsified in Tween $20(1.0 \mathrm{~mL} / \mathrm{L})$. The 7 oils mentioned in Section 2.2 were used in addition to the oil mixture (lemon + lemongrass + thyme + peppermint in equal proportions). In the control treatment, cucumber leaf discs were immersed in either sterilized distilled water or Tween $20(1.0 \mathrm{~mL} / \mathrm{L})$ for $2 \mathrm{~h}$. The conidia and conidiophores of the pathogen were scraped from the treated leaves' surfaces in $1 \mathrm{~mL}$ of sterilized distilled water, stained with methylene blue, and examined under a light microscope $(\times 400)$ for morphological malformations. The experiment was repeated three times. The degree of malformation on the fungal mycelia or conidia was placed into 1 of 4 categories: "-", no visible malformation; " + ", weak malformation in which the protoplasm shrunk away from the cell wall; " ++ ", moderate malformation in which the conidia and conidiophores showed clear plasmolysis; and ' +++ ', severe malformation in which the destruction of mycelia was observed.

\subsection{Greenhouse Experiment}

\subsubsection{Inoculum Preparation}

Sporulating colonies from the powdery mildew lesion (P. xanthii) were collected from infected plants. Conidia were detached by scraping them into sterilized water, and their concentrations were adjusted to $10^{5}$ conidia/mL in sterilized $\mathrm{H}_{2} \mathrm{O}$ using a hemocytometer slide [39]. The prepared conidial suspension was used as a potential inoculum for infecting the cucumber plants.

\subsubsection{Preparation of Essential Oil Emulsions}

For the emulsification of essential oils, the method described by Ko et al. [40] was applied by mixing $2.5 \mathrm{~mL}$ of each essential oil with Tween $20(1.0 \mathrm{~mL} / \mathrm{L})$ in sterilized distilled $\mathrm{H}_{2} \mathrm{O}(100 \mathrm{~mL})$. The mixture was shaken vigorously to achieve homogeneity and then diluted with $1 \mathrm{~L}$ of distilled water to obtain a final oil concentration of $2.5 \mathrm{~mL} / \mathrm{L}$. The freshly prepared emulsified EOs were applied directly after preparation. Distilled water or distilled water with Tween $20(1.0 \mathrm{~mL} / \mathrm{L})$ was used as the control.

\subsubsection{Experimental Procedure}

Two separate experiments ( 2 successive seasons) were conducted in a closed greenhouse during the spring seasons of 2018 and 2019 at King Khalid University, Abha City, Saudi Arabi. The greenhouse conditions included a natural day/night regime (about $12 \mathrm{~h}$ of illumination and $12 \mathrm{~h}$ of darkness), and the plants were watered to the field-capacity level. The greenhouse temperature was $15^{\circ} \mathrm{C}(\mathrm{min})$ and $27^{\circ} \mathrm{C}(\max )$, with a relative humidity of 70-90\%. The cucumber seed cultivar "Sovana F1" (Abha, Saudi Arabia) was used for the experiments. Ten seeds were sown in a $50 \mathrm{~cm}$ plastic pot containing $5 \mathrm{~kg}$ of unsterilized sandy-clay soil and peat moss $(1: 1, \mathrm{w}: \mathrm{w})$. The seeds were left to germinate and grow to approximately $15 \mathrm{~cm}$ in length, after which the plants were thinned to 3 plants per pot. The plants were irrigated regularly for 2 weeks using a constant amount of water per pot. The plants were then inoculated with a prepared inoculum of $P$. xanthii in distilled water and Tween 20 as $1.0 \mathrm{~mL} / \mathrm{L}\left(10^{5}\right.$ conidia $\left./ \mathrm{mL}\right)$. The inoculum was applied to the cucumber plants (50 mL/plant) using a spray pump. Essential oil treatments were applied $12 \mathrm{~h}$ later by spraying $50 \mathrm{~mL}$ of each essential oil $(2.5 \mathrm{~mL} / \mathrm{L})$ in the same manner. Based on the in vitro test, the concentration of $2.5 \mathrm{~mL} / \mathrm{L}$ was the most appropriate, so this concentration was chosen to carry out the greenhouse experiments. The treatments were numbered from 1 to 11, as outlined in Table 1. Pots were arranged in a complete randomized block design and watered regularly. Each replication consisted of 5 pots ( 3 plants/pot) per treatment. Experiments were repeated twice over two different seasons. Plants were sprayed every 
7 days until the flowering phase ( $\mathrm{BBCH} 6)$, and then the leaves were collected to assess the pathological, morphological, and physiological parameters. To obtain a negative control free from infection, the plants were grown in a separate part of the greenhouse and sprayed with a chemical Bayfidan fungicide (active ingredient, Triadimenol $250 \mathrm{~g} / \mathrm{L}$ ) in a concentration $0.1 \%$, with 15 -day intervals. Concentrations of essential oils higher than $2.5 \mathrm{~mL} / \mathrm{L}(3.0-5.0 \mathrm{~mL} / \mathrm{L})$ were tested on plants as an overdose assay.

Table 1. Number and description of treatments.

\begin{tabular}{cc}
\hline No. of Treatment & Description \\
\hline 1 & Positive control (PMC) * \\
2 & PMC + Distilled water + Tween 20 \\
3 & PMC + Thyme essential oil \\
4 & PMC + Lemongrass essential oil \\
5 & PMC + lemon essential oil \\
3 & PMC + Peppermint essential oil \\
7 & PMC + Abundance blend essential oil \\
8 & PMC + Purification blend essential oil \\
9 & PMC + Thieves blend essential oil \\
10 & PMC + oil mixture \\
11 & Negative control \\
\hline
\end{tabular}

* PMC $=$ Powdery mildew conidia

\subsubsection{Disease Assessment}

The severity of powdery mildew disease on cucumber plants' leaves was categorized into five groups based on the scale of Morishita et al. [41]: $0=$ no detectable infection; $1=1-5 \%$ of leaf area infected; $2=6-25 \%$ of leaf area infected; $3=26-50 \%$ leaf area infected; and $4=$ more than $50 \%$ of leaf area infected.

Disease severity was estimated using the following equation [42]:

$$
\text { Disease severity }(\%)=\left[\sum(n \times v) / 5 N\right] \times 100,
$$

where $\mathrm{n}$ refers to the number of infected leaves in each category, $\mathrm{v}$ denotes the numerical values of each category, and $\mathrm{N}$ is the total number of infected leaves.

Disease incidence (DI) was estimated using the following equation:

$$
\mathrm{DI}(\%)=(\mathrm{n} / \mathrm{N}) \times 100,
$$

where $\mathrm{n}$ is the number of infected leaves in each treatment, and $\mathrm{N}$ refers to the total number of leaves (healthy and infected).

\subsubsection{Morphological Parameters}

The resulting effects of essential-oil application on overall growth, plant length $(\mathrm{cm})$, leaf area $\left(\mathrm{cm}^{2}\right)$, and fresh and dry weights of the shoot $(\mathrm{g} / \mathrm{plant})$ were measured in treated cucumber plants at $\mathrm{BBCH}$ 6. Leaf area was measured according to the method of Cho et al. [43] using a CI-202 portable laser leaf area meter (Ave, Came, WA, USA). Leaf width was measured from tip to tip between the widest lamina lobes. The leaf length was measured from the lamina tip to the intersection of the lamina and petiole along the lamina midrib. Thirty leaves were used as replicates, and the reading was taken as the average. Dry weight was determined after drying the tissues for $72 \mathrm{~h}$ at $70^{\circ} \mathrm{C}$. The predicted yield of the cucumber fruit was then determined by counting the flowers on each plant [44].

\subsubsection{Physiological Measurements}

\section{Photosynthetic Pigments}

The spectrophotometric method was used to determine the content of chlorophyll a (Chl. a), chlorophyll b (Chl. b), and carotenoid in both the control and treated plants at BBCH 6 [45-47] using a spectrophotometer (Cary 8454 UV-Vis Diode Array System, United 
States). Photosynthetic pigments were extracted from fresh leaves in $85 \%(v / v)$ aqueous acetone. Absorbance was measured at three wavelengths $(452.5,644$, and $663 \mathrm{~nm})$ against a blank (85\% aqueous acetone). The content of each pigment was calculated using the following equations (in $\mathrm{mg} / \mathrm{g}$ fresh weight):

$$
\begin{aligned}
& \text { Chl. } \text { a content }=10.3 \times \mathrm{E} 663-0.918 \times \mathrm{E} 644=\mu \mathrm{g} / \mathrm{mL}, \\
& \text { Chl. } \mathrm{b} \text { content }=19.7 \times \mathrm{E} 644-3.87 \times \mathrm{E} 663=\mu \mathrm{g} / \mathrm{mL},
\end{aligned}
$$

Carotenoid content $=4.2 \times \mathrm{E} 452.5-[(0.0264 \times$ Chl. a $)+(0.0426 \times$ Chl. b $)]=\mu \mathrm{g} / \mathrm{mL}$, where $\mathrm{E}$ is the absorbance value.

\subsubsection{Total Carbohydrate and Protein Content}

Total carbohydrate content was assessed in the control and treated plants at BBCH 6 using the anthrone-sulfuric acid method based on the protocol described by Fales [48] and Schlegel [49]. Starch was estimated calorimetrically using an anthrone reagent, as described by Clegg [50]. Plant leaf protein content (soluble, insoluble, and total protein) was determined according to Lowry et al. [51] using bovine serum albumin as a standard.

\subsubsection{Cell Membrane Stability}

Cell membrane stability was determined in cucumber plants at BBCH 6 using the method described by Blum and Ebercon [52]. Ten leaf discs (1 cm in diameter) were washed 5 times with sterilized deionized water and placed in $30 \mathrm{~mL}$ of deionized distilled water for $24 \mathrm{~h}$ at $10{ }^{\circ} \mathrm{C}$. The electrical conductivity of the bathing solution was measured at $25^{\circ} \mathrm{C}$ using a conductometer (HANA, Model HI 991300). Following this process, leaf discs were autoclaved for $15 \mathrm{~min}$ and cooled to $25^{\circ} \mathrm{C}$; then, the electrical conductivity of the bathing solution was measured again. The degree of injury to the cell membrane was calculated based on the following equation:

$$
\text { Percentage injury }(\%)=1-[1-(\mathrm{T} 1 / \mathrm{T} 2) / 1-\mathrm{C} 1 / \mathrm{C} 2)] \times 100 \text {, }
$$

where T1 and T2 are the conductivity values before and after autoclaving the treated samples, respectively, and C1 and C2 are the conductivity values before and after autoclaving the control samples, respectively.

\subsection{Data Analysis}

The quantitative data were statistically analyzed using SPSS 22.0 (SPSS, 2013). The data were initially examined for a normal distribution of errors using a Shapiro-Wilk W test and for the homogeneity of variance using Levene's test. Data were analyzed for the significance of variation using a one-way analysis of variance (ANOVA). Means were compared using Tukey's range test at $p<0.05$ [53].

\section{Results}

\subsection{Identification of the Causal Pathogen}

Microscopic examination of the powdery mildew fungus showed the presence of an oidium-type conidiophore with cylindrical fibrosing bodies of conidia, which were identical to those of P. xanthii. Molecular identification, based on the sequences of ITS1 and ITS2 aligned with the powdery mildew fungi deposited in GenBank, confirmed the identity of the fungus as P. xanthii with a similarity level of $96.91 \%$, and its sequence data were deposited in GenBank under accession number MG243352.

\subsection{Fungitoxicity of Essential Oils on P. xanthii In Vitro}

The fungitoxic effect of essential oils on P. xanthii was evaluated in vitro. The results showed that an increase in the oil concentration increased the mycelial deformation (Table 2). The lowest concentration presented a weak effect $(+)$ as simple or weak plas- 
molysis in the protoplast of the cell (Figure 1B). There was a clear distance between the cell membrane and the cell wall compared to the control, which indicated protoplasm shrinking. Increasing the oil concentration to $1.5-2.0 \mathrm{~mL} / \mathrm{L}$ resulted in a clear deformation in the mycelial structure. The conidiophore and conidia lacked cytoplasm, and the cells suffered from strong plasmolysis, which resulted in undefined shapes (Figure 1C). The highest dose of essential oil $(2.5 \mathrm{~mL} / \mathrm{L})$ caused a clear distortion of the hyphae and conidia, which appeared as flattened thin tape (Figure 1D).

Table 2. In vitro fungitoxic effects of the essential oils on the morphology of the mycelia and conidia of Podosphaera xanthii.

\begin{tabular}{|c|c|c|c|c|}
\hline \multirow{2}{*}{ Treatment } & \multicolumn{4}{|c|}{ Concentration in $\mathrm{mL} / \mathrm{L}$} \\
\hline & 1.0 & 1.5 & 2.0 & 2.5 \\
\hline Control & - & - & - & - \\
\hline Tween 20 + Dist. Water & - & - & - & - \\
\hline Lemongrass & + & ++ & ++ & +++ \\
\hline Lemon & + & ++ & ++ & +++ \\
\hline Thyme & + & + & ++ & ++ \\
\hline Peppermint & + & + & ++ & +++ \\
\hline Thieves Blend & + & ++ & ++ & +++ \\
\hline Abundance Blend & + & ++ & ++ & +++ \\
\hline Purification Blend & + & ++ & ++ & +++ \\
\hline Oils Mixture & + & ++ & ++ & +++ \\
\hline
\end{tabular}
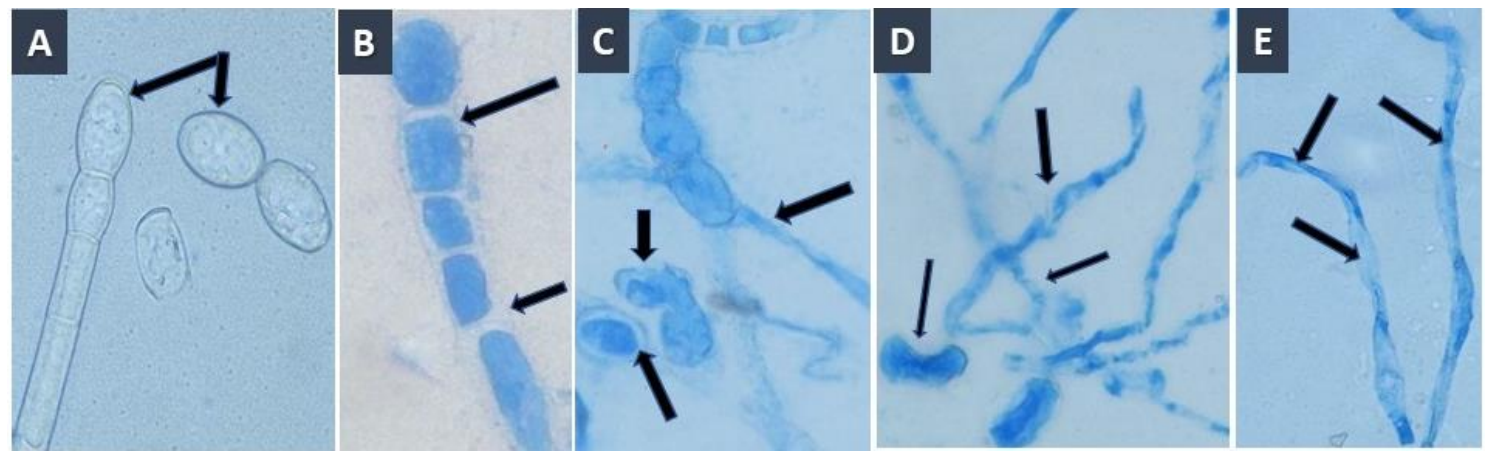

Figure 1. Fungitoxic effects of the essential-oil mixture on the structure of the mycelia and conidia of Podosphaera xanthii. Healthy and well-developed conidia in their definite shape in the control (A); mycelia and conidiophores showing some deformation, in which the protoplasm is shrinking away from the cell wall (B); strong malformations in the mycelia and conidia (C); very strong plasmolysis in the mycelia and conidia (D); and completely dead mycelia (E).

\subsection{Effect of Essential Oils on Powdery Mildew Disease Severity and Incidence}

The results demonstrated that the two experiments were associated with approximately the same pattern of disease severity in cases with and without essential-oil treatments (Figure 2). There was a significant difference between the means of the treatments in both experiments $(p<0.05)$. The application of Tween and distilled water did not lead to any considerable reduction in disease severity (up by $5.1 \pm 1.18 \%$ from the positive control). In contrast, application of the essential oils significantly $(p>0.05)$ reduced the disease severity percentage by between $65.26 \pm 1.0 \%$ and $77.26 \pm 0.18 \%$ (compared to the positive control). The highest reduction in the disease severity percentage was achieved when the oil mixture $(75.0 \pm 0.27 \%-77.26 \pm 0.18 \%)$ was applied. Consequently, essential oils significantly $(p<0.05)$ reduced the disease incidence percentage (Figure 3$)$. The highest reduction in disease incidence was observed after applying either the lemon oil $(74.42 \pm 0.31 \%-77.43 \pm 0.97 \%)$ or oil mixture $(74.19 \pm 0.21-77.06 \pm 0.29 \%)$. Photos of the oil-treated plants (Figure 4) clearly showed the differences between the positive control and 
the oil treatments, in which the essential oils mostly prevented the appearance of powdery mildew symptoms.

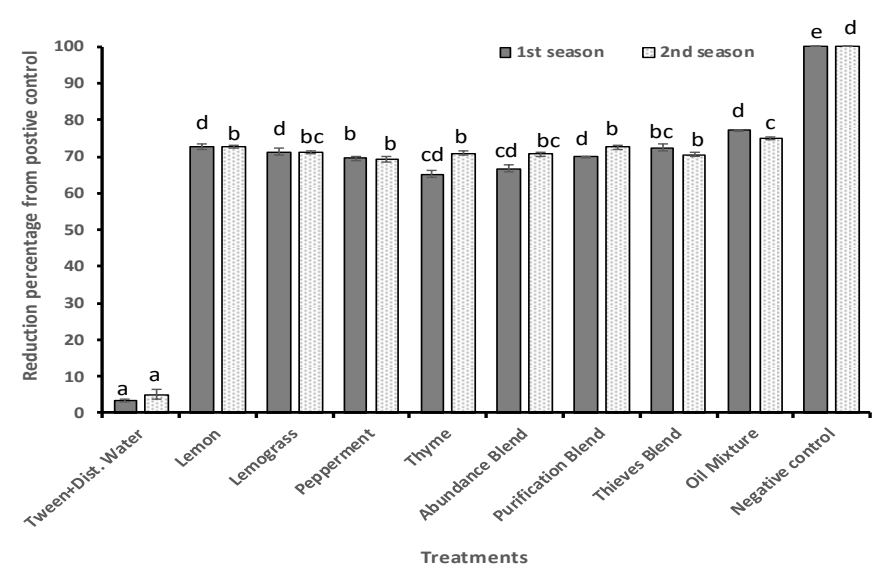

Figure 2. Effect of treatment with essential oils on the disease severity (reduction \% from the positive control) of powdery mildew on the cucumber plant. The vertical bar represents the standard error $(n=3)$. Columns in the same color and followed by different letter(s) are significantly different at $p<0.05$.

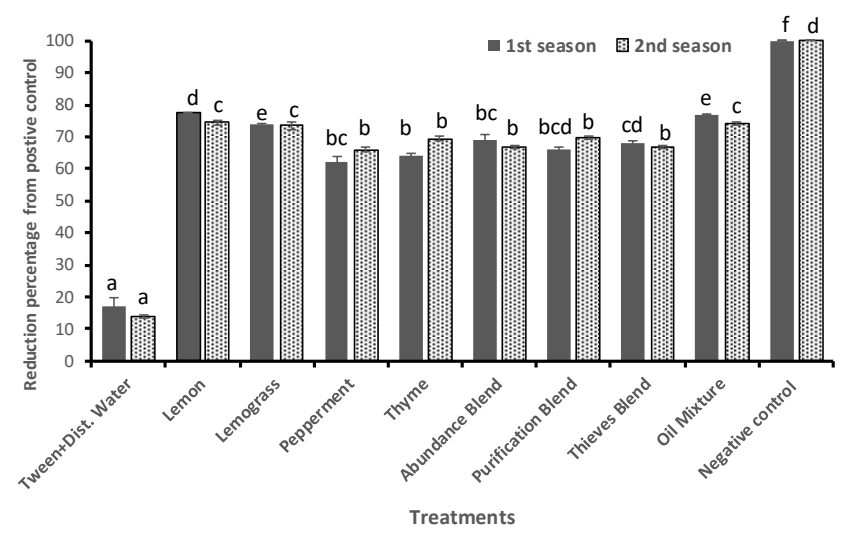

Figure 3. Effect of treatment with essential oils on the disease incidence (reduction \% from positive control) of powdery mildew on the cucumber plant. The vertical bar represents the standard error $(n=3)$. Columns in the same color and followed by different letter(s) are not significantly different at $p<0.05$.

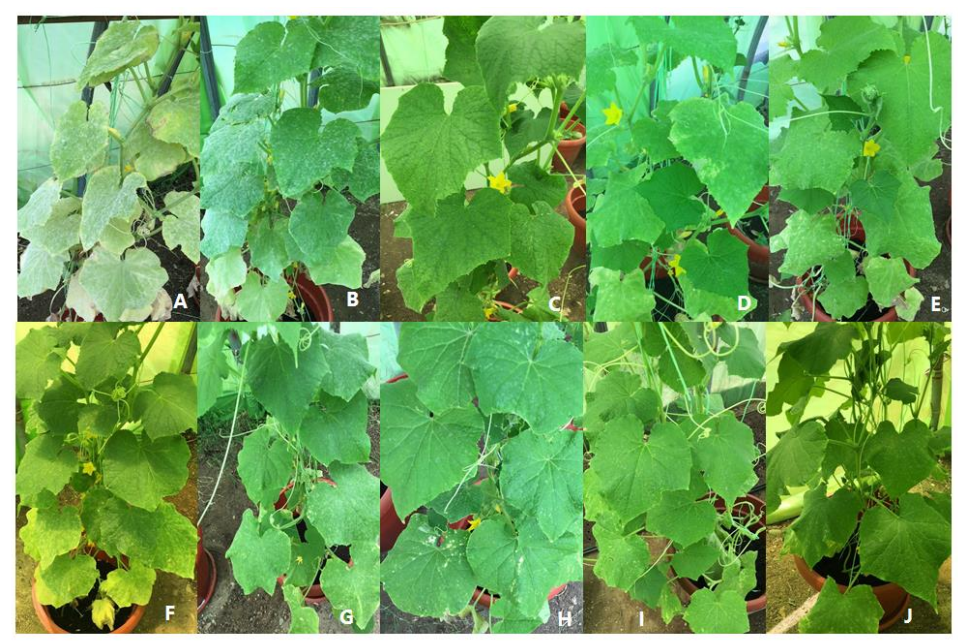

Figure 4. Untreated cucumber plants infected with powdery mildew (A) and plants treated with distilled water + tween (B), the oil mixture (C), lemon oil (D), lemongrass oil (E), thyme oil (F), peppermint oil (G), thieves-blend oil (H), abundance-blend oil (I), and the purification blend (J). 


\subsection{Consequent Effect of Essential Oils on Cucumber Plant Morphology}

The results showed that the application of essential oils resulted in significantly larger and more vigorous plants $(p<0.05)$ compared to the inoculated non-treated control. The greatest increase in plant length was recorded after application of the oil mixture $(188.8 \pm 0.17 \mathrm{~cm})$, followed by lemongrass oil $(187.0 \pm 0.15)$, during the first experiment. However, during the second experiment, the two treatments showed nearly the same results, with no significant differences between them (Table 3). Additionally, there was no significant difference between the two experiments. There was a significant increase in the leaf area up to $27.8 \pm 0.44 \mathrm{~cm}^{2}$ after the application of essential oils, compared to $24.3 \pm 0.33 \mathrm{~cm}^{2}$ in the positive control during the first experiment. The fresh and dry weight of the oil-treated plants were significantly $(p<0.05)$ higher than those of the positive control. The highest fresh weight was achieved when the oil mixture was applied $(123.2 \pm 0.42-126.3 \pm 0.16 \mathrm{~g} / \mathrm{plant})$. In the same treatment, the dry weight of the plants increased up to $23.07 \pm 0.07-22.27 \pm 0.14 \mathrm{~g} /$ plant. In all cases, the increase rate did not exceed the parameters in the negative control. A significant increase $(p<0.05)$ in the number of flowers/plant compared to the positive control was observed when the essential oils, either individually or in a mixture, were applied. The highest number of flowers / plant was 16.0-16.3 flowers/plant when the plants were treated with the thieves blend (Table 3). This was the only case in which the number of flowers/plant was higher than that in the negative control (14.0-14.3 flowers/plant).

Table 3. Effect of treatment with essential oils $(2.5 \mathrm{~mL} / \mathrm{L})$ on the morphology of the cucumber plants under greenhouse conditions.

\begin{tabular}{|c|c|c|c|c|c|c|c|c|c|c|}
\hline \multirow[b]{2}{*}{ Treatment } & \multicolumn{2}{|c|}{ Plant Length (cm) } & \multicolumn{2}{|c|}{ Leaf Area $\left(\mathrm{cm}^{2}\right)$} & \multicolumn{2}{|c|}{ Fresh Weight (g) } & \multicolumn{2}{|c|}{ Dry Weight (g) } & \multicolumn{2}{|c|}{ Number of Flower/Plant } \\
\hline & $\begin{array}{c}\text { 1st } \\
\text { Experiment }\end{array}$ & $\begin{array}{c}\text { 2nd } \\
\text { Experiment }\end{array}$ & $\begin{array}{c}\text { 1st } \\
\text { Experiment }\end{array}$ & $\begin{array}{c}\text { 2nd } \\
\text { Experiment }\end{array}$ & $\begin{array}{c}\text { 1st } \\
\text { Experiment }\end{array}$ & $\begin{array}{c}\text { 2nd } \\
\text { Experiment }\end{array}$ & $\begin{array}{c}\text { 1st } \\
\text { Experiment }\end{array}$ & $\begin{array}{c}\text { 2nd } \\
\text { Experiment }\end{array}$ & $\begin{array}{c}\text { 1st } \\
\text { Experiment }\end{array}$ & $\begin{array}{c}\text { 2nd } \\
\text { Experiment }\end{array}$ \\
\hline Positive & $150.7^{*} \pm$ & $\begin{array}{r}153.0 \pm \\
0.58 \mathrm{a}\end{array}$ & $\begin{array}{c}24.3 \pm 0.33 \\
a\end{array}$ & $24.2 \pm \underset{\mathrm{a}}{0.44}$ & $66.0 \pm \underset{a}{0.58}$ & $66.7 \pm \underset{a}{0.88}$ & $13.7 \pm \underset{\mathrm{a}}{0} 0.17$ & $\begin{array}{c}14.7 \pm 0.13 \\
\mathrm{a}\end{array}$ & $7.3 \pm 0.33 \mathrm{a}$ & $8.3 \pm 0.33 a$ \\
\hline $\begin{array}{l}\text { Tween } 20+ \\
\text { Dist. Water }\end{array}$ & $\begin{array}{c}152.7 \pm \\
0.67 \mathrm{a}\end{array}$ & $\begin{array}{c}155.3 \pm \\
0.33 \mathrm{a}\end{array}$ & $24.6 \pm 0.40$ & $\begin{array}{c}25.8 \pm 0.44 \\
\mathrm{abc}\end{array}$ & $70.3 \underset{\mathrm{b}}{ \pm} 0.33$ & $71.2 \pm 0.60$ & $15.7 \pm 0.33$ & $16.2 \pm \frac{\mathrm{a}}{\mathrm{b}} 0.17$ & $8.0 \pm 0.58 \mathrm{a}$ & $8.3 \pm 0.33 \mathrm{a}$ \\
\hline Lemongrass & $\begin{array}{r}187.0 \pm \\
0.15 \mathrm{f}\end{array}$ & $\begin{array}{r}185.3 \pm \\
0.33 \mathrm{~d}\end{array}$ & $\begin{array}{c}26.8 \pm 0.17 \\
\mathrm{bc}\end{array}$ & $\begin{array}{c}26.6 \pm 0.58 \\
b c\end{array}$ & $\begin{array}{r}116.3 \pm \\
0.88 \mathrm{~d}\end{array}$ & $\begin{array}{r}117.0 \pm \\
0.58 \mathrm{~d}\end{array}$ & $21.5 \pm 0.29$ & $22.2 \pm 0.44$ & $12.7 \pm 0.33$ & $12.3 \pm 0.33$ \\
\hline Lemon & $\begin{array}{c}183.2 \pm \\
0.60 \mathrm{e}\end{array}$ & $\begin{array}{r}183.2 \pm \\
0.17 \mathrm{~d}\end{array}$ & $27.8 \pm \underset{c}{ \pm} 0.44$ & $\begin{array}{c}26.2 \pm 0.44 \\
\mathrm{abc}\end{array}$ & $\begin{array}{c}121.7 \pm \\
0.88 \mathrm{ef}\end{array}$ & $\begin{array}{c}123.3 \pm \\
0.88 \mathrm{e}\end{array}$ & $21.5 \pm 0.47$ & $20.5 \pm \underset{c}{0} 0.29$ & $12.7 \pm 0.33$ & $13.7 \pm 0.33$ \\
\hline Thyme & $\begin{array}{c}173.2 \pm \\
1.59 \mathrm{~d}\end{array}$ & $\begin{array}{r}175.7 \pm \\
0.33 \mathrm{c}\end{array}$ & $\begin{array}{c}26.7 \pm 0.67 \\
a b c\end{array}$ & $25.3 \pm 0.67$ & $\begin{array}{c}119.2 \pm \\
0.73 \mathrm{e}\end{array}$ & $\begin{array}{r}116.8 \pm \\
0.44 \mathrm{~d}\end{array}$ & $20.7 \pm \underset{c}{ \pm} 0.33$ & $20.7 \underset{c}{ \pm} 0.33$ & $11.0 \pm \frac{\mathrm{b}}{ \pm} 0.58$ & $12.3 \pm 0.67$ \\
\hline Peppermint & $\begin{array}{c}162.5 \pm \\
0.50 \mathrm{~b}\end{array}$ & $\begin{array}{c}165.2 \pm \\
2.46 \mathrm{~b}\end{array}$ & $27.5 \pm 0.29$ & $26.7 \pm 0.44$ & $\begin{array}{r}108.7 \pm \\
0.33 \mathrm{c}\end{array}$ & $\begin{array}{r}112.3 \pm \\
0.67 \mathrm{c}\end{array}$ & $20.3 \pm \underset{c}{0} 0.33$ & $21.2 \underset{\mathrm{cd}}{ \pm} 0.44$ & $10.7 \underset{\mathrm{b}}{ \pm} 0.88$ & $11.3 \pm 0.33$ \\
\hline $\begin{array}{l}\text { Thieves } \\
\text { Blend }\end{array}$ & $\begin{array}{r}175.7 \pm \\
0.33 \mathrm{~d}\end{array}$ & $\begin{array}{c}174.7 \pm \\
1.33 \mathrm{c}\end{array}$ & $\begin{array}{c}27.0 \pm 0.58 \\
\mathrm{bc}\end{array}$ & $\begin{array}{c}25.0 \pm 0.03 \\
\mathrm{ab}\end{array}$ & $\begin{array}{r}115.3 \pm \\
0.33 \mathrm{~d}\end{array}$ & $\begin{array}{c}116.3 \pm \\
0.33 \mathrm{~d}\end{array}$ & $20.7 \pm \underset{c}{0} 0.33$ & $21.7 \pm 0.33$ & $16.0 \pm 0.58$ & $16.3 \pm 0.33$ \\
\hline $\begin{array}{l}\text { Abundance } \\
\text { Blend }\end{array}$ & $\begin{array}{r}175.7 \pm \\
0.72 \mathrm{~d}\end{array}$ & $\begin{array}{r}178.0 \pm \\
0.58 \mathrm{c}\end{array}$ & $\begin{array}{c}27.0 \pm 1.00 \\
\mathrm{bc}\end{array}$ & $\begin{array}{c}26.5 \pm 0.74 \\
\mathrm{bc}\end{array}$ & $\begin{array}{r}123.0 \pm \\
0.58 \mathrm{f}\end{array}$ & $\begin{array}{l}126.0 \pm \\
1.15 \mathrm{f}\end{array}$ & $20.0 \pm \underset{c}{ } 0.58$ & $22.5 \pm 0.29$ & $13.0 \pm 0.58$ & $13.0 \pm 0.58$ \\
\hline Purification & $166.5 \pm$ & $167.7 \pm$ & $26.0 \pm 0.58$ & $26.8 \pm 0.44$ & $116.0 \pm$ & $118.3 \pm$ & $22.7 \pm 0.33$ & $21.3 \pm 0.33$ & $12.7 \pm 0.33$ & $13.0 \pm 0.00$ \\
\hline Blend & $0.29 \mathrm{c}$ & $1.20 \mathrm{~b}$ & $a b c$ & $\mathrm{bc}$ & $0.58 \mathrm{~d}$ & $0.33 \mathrm{~d}$ & $\mathrm{~d}$ & $\mathrm{~cd}$ & $\mathrm{bc}$ & $\mathrm{bc}$ \\
\hline Oil & $188.8 \pm$ & $185.0 \pm$ & $27.6 \pm 0.49$ & $27.3 \pm 0.17$ & $123.0 \pm$ & $126.3 \pm$ & $22.7 \pm 0.33$ & $22.2 \pm 0.17$ & $13.7 \pm 0.33$ & $13.7 \pm 0.33$ \\
\hline Mixture & $0.17 \mathrm{fg}$ & $1.53 \mathrm{~d}$ & $\mathrm{c}$ & $\bar{c}$ & $1.00 \mathrm{f}$ & $0.33 \mathrm{f}$ & $\mathrm{d}$ & $\mathrm{d}$ & c & $\mathrm{c}$ \\
\hline Negative & $190.3 \pm$ & $187.4 \pm$ & $27.93 \pm$ & $27.57 \pm$ & $123.2 \pm$ & $126.3 \pm$ & $23.07 \pm$ & $22.27 \pm$ & $14.3 \pm 0.27$ & $14.0 \pm 0.46$ \\
\hline Control & $0.40 \mathrm{~g}$ & $1.58 \mathrm{~d}$ & $0.32 \mathrm{c}$ & $0.21 \mathrm{c}$ & $0.42 \mathrm{f}$ & $0.16 \mathrm{f}$ & $0.07 \mathrm{~d}$ & $0.14 \mathrm{~d}$ & $\mathrm{~cd}$ & + \\
\hline
\end{tabular}

* Mean \pm standard error $(n=3) .{ }^{* *}$ Values in the same column and followed by different letter (s) are significant different at $p<0.05$.

\subsection{Consequent Effect of Essential Oils on the Metabolic Activity of Plants}

The data revealed that the chlorophyll content was significantly $(p<0.05)$ higher in essential-oil treatments compared to that in the positive control. During the first experiment, the concentration of Chl. a was recorded as $5.78 \pm 0.01 \mathrm{mg} / \mathrm{g}$ after application of the oil mixture and was $5.22 \pm 0.23 \mathrm{mg} / \mathrm{g}$ in the case of lemongrass oil. In contrast, the highest concentration of $\mathrm{Chl} . \mathrm{b}$ and carotenoids was achieved in the positive control treatment (Table 4). 
Table 4. Effect of treatment with essential oils $(2.5 \mathrm{~mL} / \mathrm{L})$ on pigment formation $(\mathrm{mg} / \mathrm{g}$ of fresh weight) in the cucumber plants under greenhouse conditions.

\begin{tabular}{ccccccc}
\hline & \multicolumn{2}{c}{ Chlorophyll a } & \multicolumn{2}{c}{ Chlorophyll b } & \multicolumn{2}{c}{ Carotenoids } \\
\cline { 2 - 7 } Treatment & $\begin{array}{c}\text { 1st } \\
\text { Experiment }\end{array}$ & $\begin{array}{c}\text { 2nd } \\
\text { Experiment }\end{array}$ & $\begin{array}{c}\text { 1st } \\
\text { Experiment }\end{array}$ & $\begin{array}{c}\text { 2nd } \\
\text { Experiment }\end{array}$ & $\begin{array}{c}\text { 1st } \\
\text { Experiment }\end{array}$ & $\begin{array}{c}\text { 2nd } \\
\text { Experiment }\end{array}$ \\
\cline { 2 - 7 } & $2.63^{*} \pm 0.03 \mathrm{a} * *$ & $2.43 \pm 0.03 \mathrm{a}$ & $5.18 \pm 0.02 \mathrm{f}$ & $5.12 \pm 0.01 \mathrm{~g}$ & $5.30 \pm 0.03 \mathrm{f}$ & $5.03 \pm 0.01 \mathrm{~g}$ \\
Positive Control & $2.85 \pm 0.03 \mathrm{a}$ & $2.77 \pm 0.05 \mathrm{~b}$ & $3.43 \pm 0.01 \mathrm{~b}$ & $3.33 \pm 0.01 \mathrm{~b}$ & $5.52 \pm 0.00 \mathrm{~g}$ & $1.43 \pm 0.00 \mathrm{a}$ \\
Tween 20 + Dist. Water & $5.22 \pm 0.23 \mathrm{e}$ & $5.70 \pm 0.06 \mathrm{~g}$ & $3.14 \pm 0.01 \mathrm{a}$ & $3.17 \pm 0.01 \mathrm{a}$ & $3.31 \pm 0.01 \mathrm{bc}$ & $3.62 \pm 0.02 \mathrm{~d}$ \\
Lemongrass & $4.77 \pm 0.03 \mathrm{~cd}$ & $4.59 \pm 0.00 \mathrm{~d}$ & $4.09 \pm 0.03 \mathrm{~d}$ & $4.49 \pm 0.03 \mathrm{e}$ & $4.58 \pm 0.01 \mathrm{~d}$ & $4.14 \pm 0.01 \mathrm{e}$ \\
Lemon & $4.47 \pm 0.03 \mathrm{c}$ & $4.69 \pm 0.01 \mathrm{de}$ & $3.09 \pm 0.01 \mathrm{a}$ & $3.93 \pm 0.03 \mathrm{~d}$ & $3.26 \pm 0.00 \mathrm{~b}$ & $3.32 \pm 0.02 \mathrm{c}$ \\
Thyme & $4.02 \pm 0.01 \mathrm{~b}$ & $4.16 \pm 0.02 \mathrm{c}$ & $3.74 \pm 0.03 \mathrm{c}$ & $3.64 \pm 0.03 \mathrm{c}$ & $3.43 \pm 0.00 \mathrm{c}$ & $3.33 \pm 0.00 \mathrm{c}$ \\
Peppermint & $5.13 \pm 0.01 \mathrm{e}$ & $5.69 \pm 0.09 \mathrm{~g}$ & $3.67 \pm 0.03 \mathrm{c}$ & $3.63 \pm 0.01 \mathrm{c}$ & $2.04 \pm 0.01 \mathrm{a}$ & $2.12 \pm 0.01 \mathrm{~b}$ \\
Thieves Blend & $4.75 \pm 0.01 \mathrm{~cd}$ & $4.88 \pm 0.03 \mathrm{f}$ & $4.94 \pm 0.04 \mathrm{e}$ & $4.98 \pm 0.01 \mathrm{f}$ & $4.72 \pm 0.02 \mathrm{~d}$ & $4.42 \pm 0.00 \mathrm{f}$ \\
Abundance Blend & $4.82 \pm 0.04 \mathrm{~d}$ & $4.77 \pm 0.01 \mathrm{ef}$ & $5.64 \pm 0.02 \mathrm{~g}$ & $5.44 \pm 0.02 \mathrm{~h}$ & $5.09 \pm 0.02 \mathrm{e}$ & $5.12 \pm 0.01 \mathrm{~h}$ \\
Purification Blend & $5.78 \pm 0.01 \mathrm{f}$ & $5.79 \pm 0.03 \mathrm{~g}$ & $3.40 \pm 0.00 \mathrm{~b}$ & $3.32 \pm 0.02 \mathrm{~b}$ & $4.70 \pm 0.00 \mathrm{~d}$ & $4.46 \pm 0.02 \mathrm{f}$ \\
Oil Mixture & $5.83 \pm 0.01 \mathrm{f}$ & $5.84 \pm 0.03 \mathrm{~g}$ & $3.37 \pm 0.02 \mathrm{~b}$ & $3.27 \pm 0.02 \mathrm{~b}$ & $4.62 \pm 0.80 \mathrm{~d}$ & $4.48 \pm 0.03 \mathrm{f}$ \\
Negative Control & &
\end{tabular}

${ }^{*}$ Mean \pm standard error $(n=3) .{ }^{* *}$ Values in the same column and followed by different letter (s) are significant different at $p<0.05$.

The highest concentration of water-soluble carbohydrates was observed after treatment with either peppermint oil or thieves-blend oil $(5.59 \pm 0.01 \mathrm{mg} / \mathrm{g}$ DW) during the first experiment. However, during the second experiment, the highest concentration was observed after treatment with the oil mixture $(6.65 \pm 0.14 \mathrm{mg} / \mathrm{g}$ DW compared to $5.16 \pm 0.02 \mathrm{mg} / \mathrm{g}$ DW in the positive control) (Table 5). The insoluble carbohydrate content significantly increased after the application of either essential oil type in both experiments, but the highest content was detected after application of the oil mixture (32.97 $\pm 0.29-33.13 \pm 0.03 \mathrm{mg} / \mathrm{g} \mathrm{DW})$. The same results were observed for the starch formation, where the formation rate was higher in plants treated with essential oils compared to the positive control. The highest level was detected when the abundance blend was applied during the first season $(23.77 \pm 0.01 \mathrm{mg} / \mathrm{g} \mathrm{DW})$ and when the oil mixture was applied during the second experiment $(24.17 \pm 0.03 \mathrm{mg} / \mathrm{g} \mathrm{DW})$. The results showed some variation in the protein content between the first and second experiments. Application of the tested oils, either individually or in a mixture, was followed by a significant increase of the protein content $(229.43 \pm 0.09-266.34 \pm 0.22 \mathrm{mg} / \mathrm{g}$ dry weight) in the treated plants compared to the positive control (Table 6). We also observed that the increase in all metabolite content was greater than that in the negative control plants.

Table 5. Effect of treatment with essential oils $(2.5 \mathrm{~mL} / \mathrm{L})$ on carbohydrate contents and starch formation (mg/g DW) in the cucumber plants under greenhouse conditions.

\begin{tabular}{ccccccc}
\hline & \multicolumn{2}{c}{ Water Soluble Carbohydrates } & \multicolumn{2}{c}{$\begin{array}{c}\text { Total Insoluble } \\
\text { Carbohydrates }\end{array}$} & Starch \\
\cline { 2 - 8 } Treatment & $\begin{array}{c}\text { 1st } \\
\text { Experiment }\end{array}$ & $\begin{array}{c}\text { 2nd } \\
\text { Experiment }\end{array}$ & $\begin{array}{c}\text { 1st } \\
\text { Experiment }\end{array}$ & $\begin{array}{c}\text { 2nd } \\
\text { Experiment }\end{array}$ & $\begin{array}{c}\text { 1st } \\
\text { Experiment }\end{array}$ & $\begin{array}{c}\text { 2nd } \\
\text { Experiment }\end{array}$ \\
\cline { 2 - 8 } & $4.75 * \pm 0.01 \mathrm{~b}^{* *}$ & $5.16 \pm 0.02 \mathrm{a}$ & $24.11 \pm 0.01 \mathrm{~b}$ & $27.15 \pm 0.01 \mathrm{~b}$ & $17.43 \pm 0.04 \mathrm{~b}$ & $19.81 \pm 0.02 \mathrm{~b}$ \\
Positive Control & $4.48 \pm 0.01 \mathrm{a}$ & $5.54 \pm 0.01 \mathrm{~b}$ & $23.42 \pm 0.02 \mathrm{a}$ & $26.34 \pm 0.01 \mathrm{a}$ & $17.04 \pm 0.02 \mathrm{a}$ & $18.72 \pm 0.01 \mathrm{a}$ \\
Tween 20 + Dist. Water & $5.48 \pm 0.01 \mathrm{e}$ & $6.48 \pm 0.00 \mathrm{de}$ & $29.07 \pm 0.01 \mathrm{e}$ & $28.25 \pm 0.01 \mathrm{~d}$ & $21.49 \pm 0.02 \mathrm{e}$ & $22.86 \pm 0.02 \mathrm{i}$ \\
Lemongrass & $5.19 \pm 0.01 \mathrm{c}$ & $6.31 \pm 0.00 \mathrm{~d}$ & $29.33 \pm 0.01 \mathrm{e}$ & $28.31 \pm 0.01 \mathrm{e}$ & $21.73 \pm 0.01 \mathrm{e}$ & $20.79 \pm 0.02 \mathrm{e}$ \\
Lemon & $5.32 \pm 0.00 \mathrm{~d}$ & $5.32 \pm 0.01 \mathrm{ab}$ & $27.46 \pm 0.01 \mathrm{c}$ & $28.15 \pm 0.01 \mathrm{c}$ & $20.84 \pm 0.02 \mathrm{~d}$ & $20.45 \pm 0.02 \mathrm{c}$ \\
Thyme & $5.59 \pm 0.00 \mathrm{f}$ & $5.44 \pm 0.01 \mathrm{~b}$ & $27.13 \pm 0.01 \mathrm{c}$ & $29.23 \pm 0.02 \mathrm{f}$ & $19.39 \pm 0.01 \mathrm{c}$ & $20.53 \pm 0.02 \mathrm{~d}$ \\
Peppermint & $5.59 \pm 0.01 \mathrm{f}$ & $5.12 \pm 0.01 \mathrm{a}$ & $28.35 \pm 0.01 \mathrm{~d}$ & $30.15 \pm 0.02 \mathrm{~g}$ & $20.49 \pm 0.01 \mathrm{~d}$ & $21.64 \pm 0.01 \mathrm{f}$ \\
Thieves Blend & $5.33 \pm 0.00 \mathrm{~d}$ & $5.88 \pm 0.01 \mathrm{c}$ & $31.74 \pm 0.01 \mathrm{f}$ & $30.25 \pm 0.02 \mathrm{~h}$ & $23.77 \pm 0.01 \mathrm{~g}$ & $21.93 \pm 0.01 \mathrm{~g}$ \\
Abundance Blend & $5.23 \pm 0.01 \mathrm{c}$ & $5.97 \pm 0.01 \mathrm{c}$ & $28.99 \pm 0.01 \mathrm{e}$ & $30.43 \pm 0.01 \mathrm{i}$ & $21.39 \pm 0.02 \mathrm{e}$ & $22.01 \pm 0.01 \mathrm{~h}$ \\
Purification Blend & $5.46 \pm 0.04 \mathrm{e}$ & $6.57 \pm 0.02 \mathrm{e}$ & $32.62 \pm 0.01 \mathrm{~g}$ & $32.41 \pm 0.01 \mathrm{j}$ & $22.85 \pm 0.00 \mathrm{f}$ & $23.64 \pm 0.01 \mathrm{j}$ \\
Oil Mixture & $5.56 \pm 0.03 \mathrm{f}$ & $6.65 \pm 0.14 \mathrm{e}$ & $32.97 \pm 0.29 \mathrm{~g}$ & $33.13 \pm 0.03 \mathrm{k}$ & $23.5 \pm 0.24 \mathrm{~g}$ & $24.17 \pm 0.03 \mathrm{k}$ \\
Negative Control & & &
\end{tabular}

${ }^{*}$ Mean \pm standard error $(n=3) .{ }^{* *}$ Values in the same column and followed by different letter (s) are significant different at $p<0.05$. 
Table 6. Effect of treatment with essential oils $(2.5 \mathrm{~mL} / \mathrm{L})$ on the protein content $(\mathrm{mg} / \mathrm{g}$ dray weight) in the cucumber plants under greenhouse conditions.

\begin{tabular}{ccccc}
\hline & \multicolumn{2}{c}{ Soluble Protein } & \multicolumn{2}{c}{ Total Protein } \\
\cline { 2 - 5 } Treatment & $\begin{array}{c}\text { 1st } \\
\text { Experiment }\end{array}$ & $\begin{array}{c}\text { 2nd } \\
\text { Experiment }\end{array}$ & $\begin{array}{c}\text { 1st } \\
\text { Experiment }\end{array}$ & $\begin{array}{c}\text { 2nd } \\
\text { Experiment }\end{array}$ \\
\hline Positive Control & $85.67^{*} \pm 0.08 \mathrm{a} *$ & $88.31 \pm 0.03 \mathrm{a}$ & $204.32 \pm 0.04 \mathrm{a}$ & $203.32 \pm 0.53 \mathrm{a}$ \\
Tween 20 + Dist. Water & $94.86 \pm 0.07 \mathrm{~b}$ & $99.58 \pm 0.12 \mathrm{c}$ & $207.86 \pm 0.03 \mathrm{~b}$ & $202.52 \pm 0.31 \mathrm{a}$ \\
Lemongrass & $109.17 \pm 0.02 \mathrm{~g}$ & $108.30 \pm 0.06 \mathrm{~g}$ & $233.30 \pm 0.12 \mathrm{~d}$ & $243.20 \pm 0.46 \mathrm{~d}$ \\
Lemon & $107.53 \pm 0.07 \mathrm{f}$ & $108.80 \pm 0.06 \mathrm{~h}$ & $235.33 \pm 0.08 \mathrm{e}$ & $238.53 \pm 0.69 \mathrm{c}$ \\
Thyme & $106.45 \pm 0.03 \mathrm{ef}$ & $104.60 \pm 0.06 \mathrm{f}$ & $229.43 \pm 0.09 \mathrm{c}$ & $235.33 \pm 0.14 \mathrm{~b}$ \\
Peppermint & $97.97 \pm 0.07 \mathrm{c}$ & $98.60 \pm 0.06 \mathrm{~b}$ & $263.43 \pm 0.12 \mathrm{j}$ & $258.35 \pm 0.03 \mathrm{e}$ \\
Thieves Blend & $105.77 \pm 0.01 \mathrm{e}$ & $103.37 \pm 0.09 \mathrm{e}$ & $254.17 \pm 0.09 \mathrm{~h}$ & $263.24 \pm 0.72 \mathrm{f}$ \\
Abundance Blend & $100.29 \pm 0.01 \mathrm{~d}$ & $108.30 \pm 0.06 \mathrm{~g}$ & $238.73 \pm 0.69 \mathrm{f}$ & $243.54 \pm 0.41 \mathrm{~d}$ \\
Purification Blend & $99.07 \pm 0.01 \mathrm{~cd}$ & $102.96 \pm 0.01 \mathrm{~d}$ & $242.82 \pm 0.04 \mathrm{~g}$ & $239.54 \pm 0.32 \mathrm{c}$ \\
Oil Mixture & $106.85 \pm 0.22 \mathrm{ef}$ & $108.40 \pm 0.06 \mathrm{~g}$ & $253.20 \pm 0.06 \mathrm{~h}$ & $266.34 \pm 0.22 \mathrm{~g}$ \\
Negative Control & $107.20 \pm 0.82 \mathrm{f}$ & $108.93 \pm 0.18 \mathrm{~h}$ & $255.60 \pm 0.29 \mathrm{i}$ & $266.80 \pm 0.72 \mathrm{~g}$ \\
\hline
\end{tabular}

${ }^{*}$ Mean \pm standard error $(n=3)$. ${ }^{*}$ Values in the same column and followed by different letter (s) are significant different at $p<0.05$.

\subsection{Consequent Effect of Essential Oils on Cell Membrane Stability}

We observed better stability in the cell membrane of the oil-treated plants compared to the positive control. This measurement was expressed as the percentage of injury to the cell membrane (Figure 5). The results showed a significant reduction in cell membrane injury $(p<0.05)$ in the oil-treated plants compared to the positive control. The membrane injury percentage in the positive control plants was recorded as $77.3 \pm 0.36 \%$ in the first experiment and $75.8 \pm 0.36 \%$ in the second experiment. The injury percentage among plants treated with the oil mixtures was $30.37 \pm 0.33 \%$ during the first experiment and $32.5 \pm 0.23$ during the second experiment. However, the cell membrane stability in the oil-treated plants was not superior to the negative control.

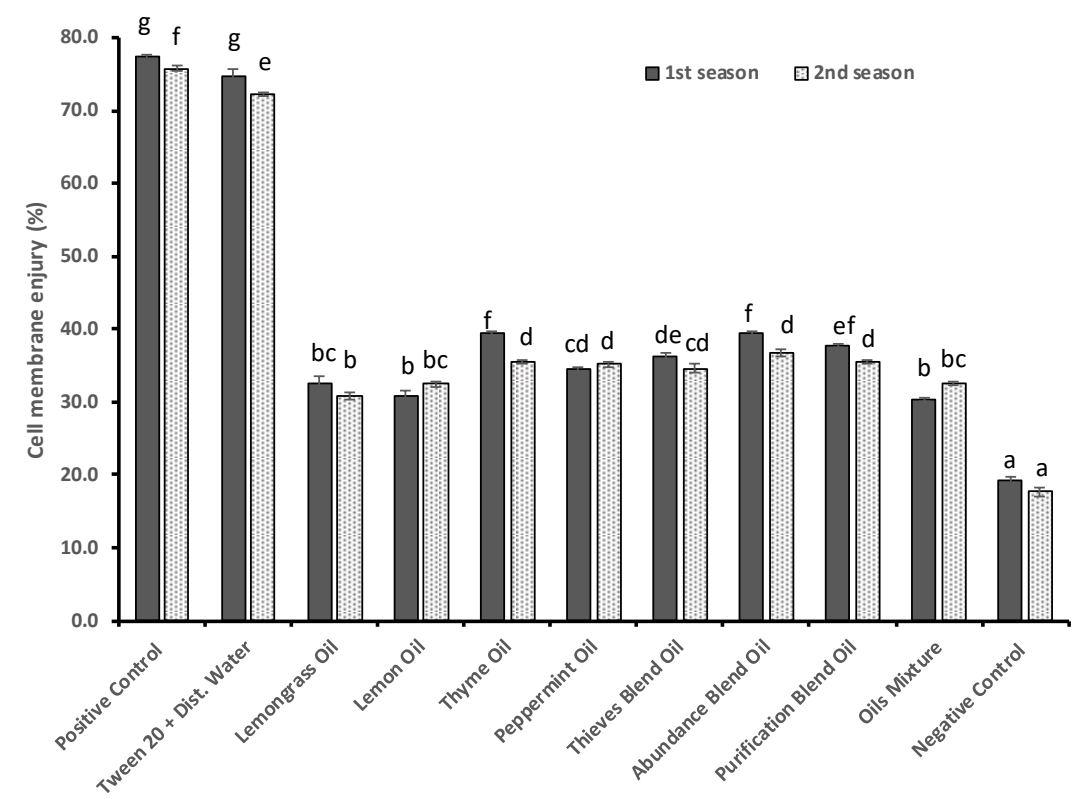

Figure 5. Effect of essential oils on the injury percentage of the cell membranes of cucumber leaves. Vertical bars represent the standard error $(n=3)$. Columns in the same color and followed by different letter(s) are significantly different at $p<0.05$. 


\subsection{Potential Adverse Effect of Overdosing with Essential Oils}

The results indicated an optimal essential oil dose of $2.5 \mathrm{~mL} / \mathrm{L}$ in all cases. A dose of 3.0-4.0 mL/L resulted in the appearance of shiny spots on the cucumber leaves (Figure 6). Moreover, when the dose reached $5.0 \mathrm{~mL} / \mathrm{L}$, complete death of the plant occurred.

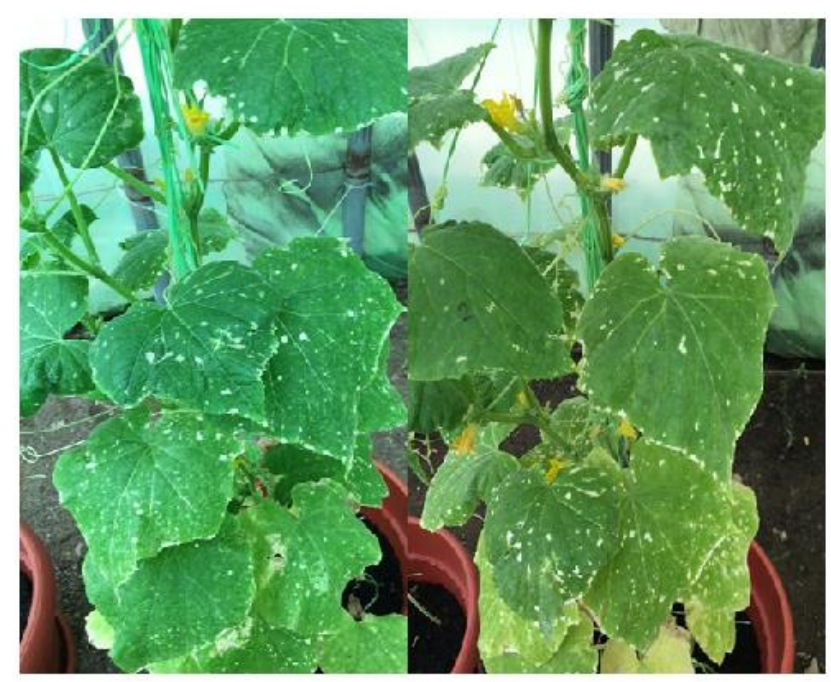

Figure 6. Adverse effects from an overdose application of essential oils on cucumber plants. Leaves show shiny spots and yellow or dead margins.

\section{Discussion}

The results of the morphological and molecular characterization of cucumber powdery mildew fungus (strain KKUY-6001) confirmed the identity of this fungus as Podosphaera xanthii. This fungus was previously described by other investigators as an obligate biotrophic pathogen that colonizes the shoot systems of many cucurbits, negatively affects host growth and physiology, and is associated with severe harvest losses $[18,25]$.

The in vitro experiments undertaken in this study demonstrated the effectiveness of essential oils, individually or in a mixture, in suppressing $P$. xanthii. An oil concentration of $2.0 \mathrm{~mL} / \mathrm{L}$ caused clear deformation in the mycelia, conidiophore, and conidia, and a concentration of $2.5 \mathrm{~mL} / \mathrm{L}$ resulted in plasmolysis and distortion of the hyphae and conidia of the pathogen, resulting in complete death of the pathogen. Tripathi et al. [54] suggested that the fungitoxicity of the essential oils may be due to their effective ingredients, including carvacrol and thymol, which have been shown to exert a suppressive effect against fungal species. While the specific mechanisms of action of these compounds against fungi have not been fully explored, the potential capabilities of these compounds to soften or disrupt the reliability of cell membranes and cell walls were previously suggested [55]. Our findings are supported by those of Ahmed [1], who found that clove, nigella, olive, and rocket oils significantly reduced the conidial germination of P. xanthii. Similarly, Raj and Shukia [56] found that clocimum and lemongrass oils caused $100 \%$ inhibition of the conidial germination of powdery mildew affecting opium poppy. Nada [57] reported that applying volatile oils as a film on slides completely prevented the spore germination of $P$. xanthii.

Our study's results showed that the application of essential oils, individually or in a mixture, significantly reduced the disease incidence and disease severity of powdery mildew in cucumber. The most effective treatment was the oil mixture, followed by lemongrass oil and lemon oil. The results of our study are consistent with those of Abd El-Sayed [58], who found that the foliar application of some plant extracts (thyme, henna, eucalyptus, and garlic), individually or in a mixture, decreased the powdery mildew intensity on cucumber compared to the control. Further, Ko, Wang, Hsieh, and Ann [40] found that canola oil, corn oil, grape seed oil, peanut oil, safflower oil, soya bean oil, and sunflower oil $(0.1 \%)$ greatly reduced the severity of tomato powdery mildew caused by Oidium neolycopersici. Sturchio, Donnarumma, Annesi, Milano, Casorri, Masciarelli, 
Zanellato, Meconi, and Boccia [18] reported that treating zucchini plants with combined clove and rosemary oil could reduce the incidence of powdery mildew under controlled conditions. Additionally, there are several reports on the efficiency of applying plant extracts and essential oils to control plant diseases, including powdery mildew, throughout the world $[9,17,59,60]$. Considering these previous reports alongside the present study, essential oils represent an important group of candidates for inclusion in IPM because essential oils are considered low-risk substances [61]. Essential oils are composite mixtures of compounds and include terpenes, such as terpinene, terpenoids, monocyclic alcohols, bicyclic alcohol, acyclic monoterpene alcohols, aromatic phenols, aliphatic aldehydes, acids, monocyclic ketones, cinnamic acid, esters, and bicyclic monoterpenic ketones [29]. These compounds may work together to suppress plant pathogenic fungi in vitro [62].

The results of our study showed a significant increase in the biomass of the essentialoil-treated plants, including plant length, leaf area, and fresh and dry weight, compared to the positive control. The increase in the plant biomass after oil treatment could confirm the efficacy of the essential oils in suppressing powdery mildew pathogens and decreasing disease severity. Consequently, the cucumber plants became healthy and free from infection, enabling the plants to undergo their normal physiological processes and achieve their normal growth parameters. In addition, the normal growth of the oil-treated plants is a good indicator of the very low phytotoxicity of essential oils when used in appropriate doses (in this case, $2.5 \mathrm{~mL} / \mathrm{L}$ ). Moreover, the observed increase in the number of flowers/plant after essential oil application is a positive indicator of an increase in the expected yield. It is reasonable to attribute this increase in the overall growth of the cucumber plants to: (1) the suppression of fungal pathogens; (2) the direct exposure of plants to growth promoters, such as phenols, which are present as fractions in essential oils; and (3) the induction of plant resistance against pathogens. Our hypothesis agrees with that of Ahmed [1], who reported that, under protected houses, the application of plant oils (e.g., clove, olive, and nigella) was followed by an increase in the number and weight of fruits per plant, as well as a noticeable increase in plant vigor

We observed that the plants infected with powdery mildew (positive control) showed low chlorophyll, carbohydrate, and protein contents compared to plants treated with essential oils. The obtained results are similar to those reported by Cheah et al. [63], who found that infection with P. xanthii reduced the photosynthetic area of cucurbit leaves. In the present study, there was a significant increase in the content of Chl. a and Chl. b due to the application of the essential oils, compared to the positive control. This result could indicate that the application of essential oils kept the cucumber plants free from infection while the leaves remained healthy and contained normal photosynthetic machines that induced normal metabolic processes. Consequently, the yields of metabolic materials, such as carbohydrates and proteins, in the oil-treated plants were higher than those in the positive control. The present findings are in partial agreement with those of Herger et al. [64], who noted that the application of an aqueous extract solution of Reynoutria sachalinensis (Milsana) leaf suppressed Erysiphe cichoracearum and P. xanthii infection and increased photosynthetic pigments in cucumber leaves. These authors suggested that the observed reduction in disease intensity may have been due to an increase in the chlorophyll content, which was reduced as a result of powdery mildew infection. Additionally, the reduction in disease incidence in cucumber plants treated with essential oils could be due to alterations in the physiology and biochemistry of plants, increases in enzyme activity, and increases in barrier defense through greater cell-wall lignification.

The present results revealed that essential oils protect cell membranes against the destruction that can be caused by fungal infection. To the best of our knowledge, there are currently no reports on the effects of either powdery mildew infection or treatment with essential oils on cell membrane stability. However, the obtained results could be supported by the findings of Hashem and Hamada [65], who noted that some biologically active materials reduced the infection of wheat roots and induced the membrane stability of plant leaves compared to the control. 


\section{Conclusions}

The results of this study confirm the efficacy of essential oils, both in vitro and in vivo and individually or in a mixture, in controlling powdery mildew disease of cucumber. The oil mixture, peppermint oil, lemongrass oil, and lemon oil were observed to be the most effective among the tested essential oils. The application of essential oils was followed by an increase in the overall growth of treated plants in terms of the plant length, leaf area, fresh and dry weight, and number of flowers. The concentrations of photosynthetic pigments and metabolites, including carbohydrates and proteins, increased after treatment with the essential-oil mixture in almost all cases. Furthermore, essential oils reduced the severity of cell membrane injury. These results suggest that essential oils could be used to protect cucumber plants against powdery mildew disease, either alone or as part of integrated pest management (IPM). However, determining the appropriate dose of each essential oil is an important factor to avoid the adverse effects of overdosing.

Author Contributions: Conceptualization, methodology, investigation, Y.S.M., M.H. and A.M.A.; validation, formal analysis, data curation, S.A., E.M.E., E.H.E.Z. and S.A.A.; writing-original draft preparation, writing-review and editing, M.H., A.M.A. and S.A.; visualization, E.H.E.Z. and S.A.A.; supervision, S.A.; project administration, M.H.; funding acquisition, Y.S.M. All authors have read and agreed to the published version of the manuscript.

Funding: This research was funded by the Deputyship for Research \& Innovation, Ministry of Education in Saudi Arabia for funding this research work through the project number IFP-KKU-2020/2.

Institutional Review Board Statement: Not applicable.

Informed Consent Statement: Not applicable.

Acknowledgments: The authors extend their appreciation to the Deputyship for Research \& Innovation, Ministry of Education in Saudi Arabia for funding this research work through the project number IFP-KKU-2020/2.

Conflicts of Interest: The authors declare no conflict of interest.

\section{References}

1. Ahmed, G.A. Using plant extracts to control powdery mildew disease that attack cucumber plants under protected houses. M. Sc. Fac. Agric. Moshtohor. Zagazig Univ. Benha Branch. 2005, 175.

2. Essa, T.A.; El-Gamal, A.H.M.; Afifi, M.M.I. Control of cucumber downy mildew by some plant growth promoting Rhizobacteria under greenhouse conditions. Middle East J. Agri. Res. 2017, 6, 395-408.

3. FOASTAT. Food and Agriculture Organization of the United Nations. Available online: https://www.fao.org/faostat/en/ \#search/Cucumbers\%20and\%20gherkins (accessed on 14 November 2021).

4. Saudi-Arabia.Cropscience.Bayer Crop Science- Saudi Arabia. Available online: https://www.saudi-arabia.cropscience.bayer. com/ar/Crops/Cucumber.aspx (accessed on 1 September 2021).

5. Pal, A.; Adhikary, R.; Shankar, T.; Sahu, A.K.; Maitra, S. Cultivation of Cucumber in Greenhouse. In Protected Cultivation and Smart Agriculture; Sagar Maitra, D.J.G.A.T.S., Ed.; New Delhi Publishers: New Delhi, India, 2020; pp. $139-145$.

6. Diab, Y.A.; Mousa, M.A.; Abbas, H.S. Greenhouse-grown Cucumber as an Alternative to Field Production and its Economic Feasibility in Aswan Governorate, Egypt. Assiut J. Agric. Sci. 2016, 47, 122-135.

7. Al-Harbi, A.R.; Al-Omran, A.M.; Alharbi, K. Grafting improves cucumber water stress tolerance in Saudi Arabia. Saudi J. Biol. Sci. 2018, 25, 298-304. [CrossRef] [PubMed]

8. Ministry of Agriculture. Agriculture Statistical Yearbook; Ministry of Agriculture: Riyadh, Kingdom of Saudi Arabia, 2014; Volume 27.

9. Elsharkawy, M.M.; Kamel, S.M.; El-Khateeb, N. M Biological control of powdery and downy mildews of cucumber under greenhouse conditions. Egypt. J. Biol. Pest Cont. 2014, 24, 301-308.

10. Trecate, L.; Sedláková, B.; Mieslerová, B.; Manstretta, V.; Rossi, V.; Lebeda, A. Effect of temperature on infection and development of powdery mildew on cucumber. Plant Pathol. 2019, 68, 1165-1178. [CrossRef]

11. Bettiol, W.; Silva, H.S.A.; Reis, R.C. Effectiveness of whey against zucchini squash and cucumber powdery mildew. Scientia Hort. 2008, 117, 82-84. [CrossRef]

12. Lebeda, A.; Křístková, E.; Sedláková, B.; McCreight, J.D.; Kosman, E. Virulence variation of cucurbit powdery mildews in the Czech Republic-population approach. Eur. J. Plant Pathol. 2018, 152, 309-326. [CrossRef]

13. Pérez-Garcia, A.; Olalla, L.; Rivera, E.; Del Pino, D.; Cánovas, I.; De Vicente, A.; Torés, J.A. Development of Sphaerotheca fusca on susceptible, resistant, and temperature-sensitive resistant melon cultivars. Mycol. Res. 2001, 105, 1216-1222. [CrossRef] 
14. Kuzuya, M.; Yashiro, K.; Tomita, K.; Ezura, H. Powdery mildew (Podosphaera xanthii) resistance in melon is categorized into two types based on inhibition of the infection processes. J. Exp. Bot. 2006, 57, 2093-2100. [CrossRef] [PubMed]

15. Kimati, H.; Amorim, L.; Bergamin Filho, A.; Camargo, L.E.A.; Rezende, J.A.M. Manual de Fitopatologia: Doenças das Plantas Cultivadas; Agronômica Ceres São Paulo: São Paulo, Brazil, 1997; Volume 2, p. 705.

16. Özkara, A.; Akyıl, D.; Konuk, M. Pesticides, Environmental Pollution, and Health. In Environmental Health Risk-Hazardous Factors to Living Species; IntechOpen: London, UK, 2016.

17. Rur, M.; Rämert, B.; Hökeberg, M.; Vetukuri, R.R.; Grenville-Briggs, L.; Liljeroth, E. Screening of alternative products for integrated pest management of cucurbit powdery mildew in Sweden. Eur. J. Plant Pathol. 2018, 150, 127-138. [CrossRef]

18. Sturchio, E.; Donnarumma, L.; Annesi, T.; Milano, F.; Casorri, L.; Masciarelli, E.; Zanellato, M.; Meconi, C.; Boccia, P. Essential oils: An alternative approach to management of powdery mildew diseases. Phytopath. Medit. 2014, 53, 385-395.

19. IPM-Missouri Cucumber Downy Mildew. Available online: https://ipm.missouri.edu/MEG/2019/8/cucumberDownyMildew/ (accessed on 23 August 2021).

20. Zhang, S.; Mersha, Z.; Vallad, G.E.; Huang, C.-H. Management of powdery mildew in squash by plant and alga extract biopesticides. Plant Pathol. J. 2016, 32, 528. [CrossRef] [PubMed]

21. Koul, O. Microbial biopesticides: Opportunities and challenges. Biocont. News Inform. 2012, 33, 1R.

22. Moyer, C.; Peres, N.A. Evaluation of biofungicides for control of powdery mildew of gerbera daisy. In Proceedings of the Florida State Horticultural Society, Fort Lauderdale, FL, USA, 1-4 June 2008; pp. 389-394.

23. Cornell-Vegetables Biopesticides for Managing Diseases of Cucurbits Organically. Available online: https://www.vegetables.cornell. edu/ipm/diseases/biopesticides/biopesticides-for-managing-diseases-of-cucurbits-organically/ (accessed on 3 June 2021).

24. Lamichhane, J.R.; Bischoff-Schaefer, M.; Bluemel, S.; Dachbrodt-Saaydeh, S.; Dreux, L.; Jansen, J.P.; Kiss, J.; Köhl, J.; Kudsk, P.; Malausa, T. Identifying obstacles and ranking common biological control research priorities for Europe to manage most economically important pests in arable, vegetable and perennial crops. Pest Manage. Sci. 2017, 73, 14-21. [CrossRef]

25. Gilardi, G.; Baudino, M.; Garibaldi, A.; Gullino, M.L. Efficacy of biocontrol agents and natural compounds against powdery mildew of zucchini. Phytoparasitica 2012, 40, 147-155. [CrossRef]

26. Hammer, K.A.; Carson, C.F.; Riley, T.V. Antimicrobial activity of essential oils and other plant extracts. J. Appl. Microbiol. 1999, 86, 985-990. [CrossRef]

27. Hashem, M.; Moharam, A.M.; Zaied, A.A.; Saleh, F.E.M. Efficacy of essential oils in the control of cumin root rot disease caused by Fusarium spp. Crop Protect. 2010, 29, 1111-1117. [CrossRef]

28. Znini, M.; Cristofari, G.; Majidi, L.; Mazouz, H.; Tomi, P.; Paolini, J.; Costa, J. Antifungal activity of essential oil from Asteriscus graveolens against postharvest phytopathogenic fungi in apples. Nat. Prod. Communic. 2011, 6, 1763. [CrossRef]

29. Arshad, Z.; Hanif, M.A.; Qadri, R.W.K.; Khan, M.M.; Babarinde, A.; Omisore, G.O.; Babalola, J.O.; Syed, S.; Mahmood, Z.; Riaz, M. Role of essential oils in plant diseases protection: A review. Int. J. Chem. Biochem. Sci. 2014, 6, 11-17.

30. Nguefack, J.; Nguikwie, S.; Fotio, D.; Dongmo, B.; Zollo, P.A.; Leth, V.; Nkengfack, A.; Poll, L. Fungicidal potential of essential oils and fractions from Cymbopogon citratus, Ocimum gratissimum and Thymus vulgaris to control Alternaria padwickii and Bipolaris oryzae, two seed-borne fungi of rice (Oryza Sativa L.). J. Essent. Oil Res. 2007, 19, 581-587. [CrossRef]

31. Kishore, G.K.; Pande, S.; Harish, S. Evaluation of essential oils and their components for broad-spectrum antifungal activity and control of late leaf spot and crown rot diseases in peanut. Plant Dis. 2007, 91, 375-379. [CrossRef] [PubMed]

32. Raveau, R.; Fontaine, J.; Lounès-Hadj Sahraoui, A. Essential oils as potential alternative biocontrol products against plant pathogens and weeds: A review. Foods 2020, 9, 365. [CrossRef] [PubMed]

33. Koul, O.; Walia, S.; Dhaliwal, G. Essential oils as green pesticides: Potential and constraints. Biopest. Int. $2008,4,63-84$.

34. Mohan, M.; Haider, S.Z.; Andola, H.C.; Purohit, V.K. Essential oils as green pesticides: For sustainable agriculture. Research J. Pharm. Biol. Chem. Sci. 2011, 2, 100-106.

35. Braun, U.; Takamatsu, S. Phylogeny of Erysiphe, Microsphaera, Uncinula (Erysipheae) and Cystotheca, Podosphaera, Sphaerotheca (Cystotheceae) inferred from rDNA ITS sequences-Some taxonomic consequences. Schlechtendalia 2000, 4, 1-33.

36. White, T.J.; Bruns, T.; Lee, S.; Taylor, J.L. Amplification and direct sequencing of fungal ribosomal RNA genes for phylogenetics. PCR Protoc. A Guide Meth. Appl. 1990, 18, 315-322.

37. Chen, R.-S.; Chu, C.; Cheng, C.-W.; Chen, W.-Y.; Tsay, J.-G. Differentiation of two powdery mildews of sunflower (Helianthus annuus) by a PCR-mediated method based on ITS sequences. Eur. J. Plant Pathol. 2008, 121, 1-8. [CrossRef]

38. Nelson, H. Bioassay to detect small differences in resistance of tomato to late blight according to leaf age, leaf and leaflet position, and plant age. Aust. Plant Path. 2006, 35, 297-301. [CrossRef]

39. Rodriguez-Tudela, J.L.; Arendrup, M.C.; Arikan, S.; Barchiesi, F.; Bille, J.; Chryssanthou, E.; Cuenca-Estrella, M.; Dannaoui, E.; Denning, D.W.; Donnelly, J.P. EUCAST DEFINITIVE DOCUMENT E. DEF 9.1: Method for the determination of broth dilution minimum inhibitory concentrations of antifungal agents for conidia forming moulds. Def. Sci. J. 2008, 9, 1-13.

40. Ko, W.H.; Wang, S.Y.; Hsieh, T.F.; Ann, P.J. Effects of sunflower oil on tomato powdery mildew caused by Oidium neolycopersici. J. Phytopathol. 2003, 151, 144-148. [CrossRef]

41. Morishita, M.; Sugiyama, K.; Saito, T.; Sakata, Y. Powdery mildew resistance in cucumber. Jpn. Agric. Res. Q. JARQ 2003, 37, 7-14. [CrossRef]

42. Waller, J.; Cannon, P. Fungi as Plant Pathogens. In Plant Pathologist's Pocketbook, 3rd ed.; CABI Publishing: Boston, MA, USA, $2002 ;$ p. 85. 
43. Cho, Y.Y.; Oh, S.; Oh, M.M.; Son, J.E. Estimation of individual leaf area, fresh weight, and dry weight of hydroponically grown cucumbers (Cucumis sativus L.) using leaf length, width, and SPAD value. Scientia Hort. 2007, 111, 330-334. [CrossRef]

44. Wehner, T.C.; Guner, N. Growth stage, flowering pattern, yield, and harvest date prediction of four types of cucumber tested at 10 planting dates. In Proceedings of the XXVI International Horticultural Congress: Advances in Vegetable Breeding 637, Toronto, ON, Canada, 11-17 August 2002; pp. 223-230.

45. Metzner, H.; Rau, H.; Senger, H. Untersuchungen zur synchronisierbarkeit einzelner pigmentmangel-mutanten von Chlorella. Planta 1965, 65, 186-194. [CrossRef]

46. Costache, M.A.; Campeanu, G.; Neata, G. Studies concerning the extraction of chlorophyll and total carotenoids from vegetables. Roman. Biotech. Lett. 2012, 17, 7702-7708.

47. McLeroy-Etheridge, S.L.; McManus, G.B. Food type and concentration affect chlorophyll and carotenoid destruction during copepod feeding. Limnol. Oceanogr. 1999, 44, 2005-2011. [CrossRef]

48. Fales, F.W. The assimilation and degradation of carbohydrates by yeast cells. J. Biol. Chem. 1951, 193, 113-124. [CrossRef]

49. Schlegel, H.G. The recovery of organic acid by Chlorella in the light. Planta 1956, 47, 510-526. [CrossRef]

50. Clegg, K. The application of the anthrone reagent to the estimation of starch in cereals. J. Sci. Food Agric. 1956, 7, 40-44. [CrossRef]

51. Lowry, O.H.; Rosebrough, N.J.; Farr, A.L.; Randall, R.J. Protein measurement with the Folin phenol reagent. J. Biol. Chem. 1951, 193, 265-275. [CrossRef]

52. Blum, A.; Ebercon, A. Cell membrane stability as a measure of drought and heat tolerance in wheat. Crop Sci. 1981, 21, 43-47. [CrossRef]

53. Snedecor, G.; Cochran, W. Statistical Methods; Iowa State University: Ames, IA, USA, 1980.

54. Tripathi, A.K.; Prajapati, V.; Kumar, S. Bioactivities of l-carvone, d-carvone, and dihydrocarvone toward three stored product beetles. J. Econ. Entomol. 2003, 96, 1594-1601. [CrossRef] [PubMed]

55. Isman, M.B.; Machial, C.M. Pesticides based on plant essential oils: From traditional practice to commercialization. Adv. Phytomed. 2006, 3, 29-44.

56. Raj, K.; Shukia, D.S. Evaluation of some innovative vis a vis powdery mildew of opium poppy incited by Erysiphe polygoni. J. Living World 1996, 3, 12-17.

57. Nada, M.G.A. Studies on Antifungal Activities of Some Egyptian Medical and Aromatic plants. Ph. D. Thesis, Faculty of Agriculture, Zagazig University, Zagazig, Egypt,, 2002; p. 163.

58. Abd El-Sayed, M.H.F. Studies on Powdery Mildew Disease of Cucurbits Under Protected Cultivation. Master's Thesis, Plant Pathology Department, Faculty of Agriculture, Cairo University,, Cairo, Egypt, 2000.

59. Utkhede, R.S.; Koch, C.A. Reduction of powdery mildew caused by Podosphaera xanthii on greenhouse cucumber plants by foliar sprays of various biological and chemical agents. J. Horticult. Sci. Biotechnol. 2006, 81, 23-26.

60. Jee, H.-J.; Shim, C.-K.; Ryu, K.-Y.; Park, J.-H.; Lee, B.-M.; Choi, D.-H.; Ryu, G.-H. Control of powdery and downy mildews of cucumber by using cooking oils and yolk mixture. Plant Pathol. J. 2009, 25, 280-285. [CrossRef]

61. Villaverde, J.J.; Sandín-España, P.; Sevilla-Morán, B.; López-Goti, C.; Alonso-Prados, J.L. Biopesticides from natural products: Current development, legislative framework, and future trends. BioResources 2016, 11, 5618-5640. [CrossRef]

62. Kordali, S.; Cakir, A.; Mavi, A.; Kilic, H.; Yildirim, A. Screening of chemical composition and antifungal and antioxidant activities of the essential oils from three Turkish Artemisia species. J. Agric. Food Chem. 2005, 53, 1408-1416. [CrossRef] [PubMed]

63. Cheah, L.H.; Page, B.B.C.; Cox, J.K. Epidemiology of powdery mildew (Sphaerotheca fuliginea) of squash. N. Z. Plant Protec. Soc. 1996, 49, 147-151. [CrossRef]

64. Herger, G.; Klingauf, F.; Mangold, D.; Pommer, E.H.; Scherer, M. Efficacy of extracts of Reynoutria sachalinensis (F. Schmidt) Nakai (Polygonaceae), against fungal diseases, especially powdery mildews. Nachrichtenblatt des Deutschen Pflanzenschutzdienstes 1988, $40,56-60$.

65. Hashem, M.; Hamada, A.M. Evaluation of two biologically active compounds for control of wheat root rot and its causal pathogens. Mycobiology 2002, 30, 233-239. [CrossRef] 